\title{
FSSC 22000 Packaging Implementation: a Plastics Industry Research
}

\author{
Vanessa Cantanhede $^{1 *}$, Karen Signori Pereira ${ }^{2}$ and Daniel Weingart Barreto ${ }^{3}$ \\ ${ }^{1}$ Chemistry School, Universidade Federal do Rio de Janeiro - UFRJ, Rio de Janeiro, RJ, Brazil \\ ${ }^{2}$ Biochemical Engineering, Chemistry School, Universidade Federal do Rio de Janeiro - UFRJ, \\ Rio de Janeiro, RJ, Brazil \\ ${ }^{3}$ Organic Processes, Chemistry School, Universidade Federal do Rio de Janeiro - UFRJ, \\ Rio de Janeiro, RJ, Brazil \\ *vanessacantanhede@gmail.com
}

\begin{abstract}
This paper presents the outcomes of an exploratory research carried out in companies, which are located in Brazil. They are FSSC-22000-certified food plastic packaging manufacturers. In order to identify the key aspects of the implementation process and certification, a questionnaire was developed and sent to twenty certified organizations. Out of them, eleven of which participating companies responded in a collaborative way. Based on the data obtained, improving competitiveness and customer retention were the reasons, which led the companies to seek the certification. However, the greatest difficulties were related to personnel, which presented technical and behavioral issues. In addition, it was noted that an overall satisfaction, derived from after-certification benefits, has been arisen in the companies. For instance, enhanced employee awareness, improved company's image and winning new customers, significantly contributing to their competitiveness, are some of the benefits found in this process.
\end{abstract}

Keywords: food safety, FSSC 22000, packaging, plastic.

\section{Introduction}

Since the 1990s, a significant change has taken place in Brazilian industries mainly due to trade liberalization. In addition, the pursuit of competitiveness has become their focus. As a result of both internal (defect reduction) and external motivators (increased customer satisfaction), quality programs have been valued and implemented by organizations as a response to new economic conditions ${ }^{[1]}$. Therefore, companies have adopted quality assurance systems based on international standards, such as ISO 9001, in this particular case ${ }^{[2]}$. It is extremely important, due to the fact that international standards and norms facilitate trade among countries, help ensure technical compatibility and feasibility of marketed products. Besides, it also generates product reliability.

Simultaneously, because of trade liberalization, a relevant growth in food imports took place in Brazil. From 1992 to 1995 , the import of processed food grew by $409 \% 0^{[3]}$. Due to the wide range of products and services, marketed worldwide, economic globalization and industrialization play an important role. Currently, the scenario is highly competitive and Brazil is ranked among the world's largest food exporters. In addition, in agribusiness, including the export of coffee beans, soybeans and raw material, Brazil holds the 5 th place ${ }^{[4]}$. Food and beverage industries' production represent $9.5 \%$ of the Brazilian Gross Domestic Product (GDP), in addition to creating an increasing number of jobs, generating a greater balance of trade, if compared to the other economy sectors ${ }^{[5]}$.

However, it is very important to note that, in addition to market expansion, trade liberalization and the progressive industrialization, there were several changes in the food industry, both in production and in marketing. One of the main changes was the increased social concern on food safety, which is already considered a global public health issue by the World Health Organization (WHO).

Food Safety is related to the concept that indicates the food will not cause any harm to the consumer's health when prepared and/or eaten according to its intended use $\mathrm{e}^{[6]}$. Thus, increasingly competitive strategies are developed by the agri-food industry groups, in order to win consumer confidence in quality, provenance and food safety ${ }^{[7]}$, ensuring that consumer health is not affected.

Among the different packaging markets, the plastic packaging segment stands out. Between 2007 and 2011, its value (US\$) grew by $7.9 \%$ per year, highlighting the food and beverage industry, as the largest consumer ${ }^{[8]}$. It also had the highest share in production value, corresponding to $39.07 \%$ of the total in $2014^{[9]}$. Thus, the high consumption of plastic packaging for the food industry and the expansion of this sector were the main reasons to choose the plastics segment for this research paper.

Packages have a prominent role in the food supply chain and are essential to ensure product safety. The growth of this sector follows the food industry development and, according to ABRE (Brazilian Packaging Association), the packaging sector currently generates $\mathrm{R} \$ 47$ billion (Brazilian currency) and more than 200,000 direct and formal jobs ${ }^{[10]}$. 
The food safety subject in the packaging industry has been getting more and more relevance in recent years. It can be evidenced by the recent publication of an international standard. The FSSC 22000 contains a complete certification Scheme for Food Safety Management Systems based on existing standards for certification (ISO 22000 and technical specifications for sector PRPs). It is considered complete and the latest certification scheme for food safety systems ${ }^{[11]}$.

The FSSC 22000 scheme was given full recognition in 2010 by the Global Food Safety Initiative (GFSI). It is an industry-driven initiative providing guidance on food safety management systems, wich are necessary for safety throughout the supply chain. This work is accomplished through collaboration between the world's leading food safety experts from retail, manufacturing and food service companies, as well as international organizations, governments, academia and service providers to the global food industry. GFSI's vision is to provide safe food for consumers everywhere ${ }^{[11]}$. In 2011, a specific version for the food packaging segment was published (FSSC 22000 Packaging), and brought a new market perspective, emphasizing the need to ensure that products are free from contaminants throughout the food chain.

Already, 10.000 more organizations over 140 countries achieved FSSC 22000 certification. In Brazil, 291 certified companies, and among these, 66 are food-packaging industries. These data were verified in July 2015 during the present study and it confirms the growth and adherence of companies to the FSSC 22000 certification $^{[12]}$.

This paper mainly aims to evaluate the FSSC 22000 implementation process in plastic packaging companies for the food industry and certification impacts regarding competitiveness of those companies in the packaging market.

Therefore, a survey was conducted in certified organizations established in Brazil, which identified the profile of those companies, the drivers to obtain certification, the main facilitators and challenges faced during the implementation of this standard, and the effects achieved through the implementation of FSSC 22000.

\section{Materials and Methods}

\subsection{Questionnaire elaboration}

As from bibliographic research to scientific articles published in the last five years, addressing issues concerning the benefits and difficulties in management systems and specifically in food safety systems, a questionnaire template was designed for FSSC 22000 standard certified packaging industries.

The questions were developed so as not to have direct intervention nor influence of the researcher on researches ${ }^{[13]}$. By the exploratory approach of the research, most questions were created in such a way in order not to induce responses, thus it promoted room for spontaneous responses by informants.

The questionnaire was structured as follows. The first part features the participating companies, the number of employees, year of foundation, company size, the market where it operates and location. The second part characterizes the standard implementation process and its duration, for example "what were the reasons to adopt the standard?"; "In which of the options, the company had higher expenses / financial investments?"; "What were the difficulties faced"; "it were necessary to hire an external advice firm?. The third part, which aims to identify the benefits and the satisfaction level, obtained after the certification.

The finalized questionnaire was validated by professionals from this universe, as a pilot test, to be studied, before it was effectively sent to the companies, as suggested in literature ${ }^{[14]}$. As a result of this validation, changes were made in a few questions.

\subsection{Sampling}

As from the evaluation certified organizations' database, available on the certificates directory of Foundation for Food Safety Certification website ${ }^{[12]}$, only plastics segment companies, which are located in the country, were selected. In total, 20 plastics manufacturers had the FSSC 22000 Packaging certification when the consultation was carried out in August 2015. For this survey, in the analysis made by sectors within the plastics industry, company groups were established according to the type of product they manufacture. And it is represented in Table 1.

\subsection{Conducting the Questionnaire Survey}

The questionnaire was electronically sent via e-mail to those who were responsible for the Quality department at the selected companies. $55 \%$ of the questionnaires were effectively responded. It is important to mention that, before sending them, each company was contacted by telephone, in order to present and explain the survey. All the process, from the first contact with the organizations to the final data compilation, took place between August 2015 and December 2015. Due to the difficulty with colleting the organizations' responses, this process was long.

The information asked in the questionnaires was individually evaluated. Besides the data collected were tabulated in order to systematize the all pieces of information. Thus, they were grouped up so that they could be statistically analyzed.

\section{Results and Discussions}

\subsection{Characterization of responding organizations}

The respondent's company position was asked in the questionnaire. All of them work as quality managers or quality coordinators, according to the information

Table 1. FSSC 22000 certified plastic packaging companies, classified by sector and number of manufacturing sites in Brazil.

\begin{tabular}{lcc}
\hline \multicolumn{1}{c}{ Sectors } & $\begin{array}{c}\mathbf{N}^{\mathbf{0}} \text { of } \\
\text { Companies }\end{array}$ & $\mathbf{N}^{\mathbf{0}}$ of Factories \\
\hline Polyethylene covers & 6 & 8 \\
Preforms and PET bottles & 8 & 29 \\
Polyethylene films and bags & 1 & 1 \\
Polypropylene big bag & 1 & 1 \\
Thermoformed polypropylene cup & 1 & 3 \\
Polyethylene containers & 3 & 11 \\
Total & $\mathbf{2 0}$ & $\mathbf{5 3}$ \\
\hline
\end{tabular}


gathered. This piece of information increases the chances that questionnaire responses were given by employees who have a holistic view of the organization and deep knowledge of quality and product safety, that is, those who are directly involved with FSSC22000.

Out of the organizations surveyed, seven are multinationals, located in Brazil, and five of them are national companies. Most of them have been operating in the market segment for more than ten years. According to the participating companies, nine out of the 11 companies are located in southern and southeastern Brazil. Therefore, these Brazilian regions are the places where the largest number of certified companies is found.

The size of each company was evaluated, considering the annual gross operating revenue, according to the criteria defined by BNDES (National Development Bank) ${ }^{[15]}$. Such evaluation indicated that $73 \%$ is classified as large companies, $18 \%$ medium-to-large companies and other $9 \%$ as small businesses. The majority (64\%) sells in the domestic market and exports to other countries.

The number of employees of each participating organization was also evaluated. Therefore, it was found that $63 \%$ of the responding organizations have 101 to 200 employees and only $18 \%$ have over 300 employees.

Before the FSSC 22000 implementation, 80\% of the companies already had some other certified management system, being at least the quality management standard ISO 9001. This one is the basis for expansion of a quality system, and its certification measures the effectiveness of the system in international standards. If the activity related to food safety was previously established, it was also analyzed. Once these companies are packaging suppliers for food and beverages, it is common that customers require at least good manufacturing practices, which are the basic and necessary activities to ensure a hygienic and safe environment ${ }^{[6]}$. However only two out of the eleven companies responded there was not any practice implemented. These data are shown in the Table 2.

\subsection{Analysis of the standard implementation process}

\subsubsection{Motivations for the FSSC 22000 certification}

Unlike other management standards, such as ISO 9001, whose certification is currently consolidated in Brazil and worldwide, as a competitive and strategic advantage, and in many cases as a contractual requirement between companies ${ }^{[16]}$, FSSC 22000 is not widespread yet. This way, the certification has been recently obtained by organizations. Thus, the intention for conquering the certification was evaluated.

The motivations for the certification of a standard can be classified into two categories: internal and external motivations. The internal one is related to the organization improvement, for example, the improvement of the management system, increased productivity, increased company's revenue, enhanced employee awareness, reduction of non-compliance, among others. On the other hand, the external one is related to marketing, pressure applied by the customer and increased market share ${ }^{[17]}$.
Table 2. Profile of responding companies before starting the FSSC 22000 implementation.

\begin{tabular}{ccc}
\hline Company & Certification (ISO) & $\begin{array}{c}\text { Activity related to } \\
\text { Food Safety }\end{array}$ \\
\hline A & Yes & HACCP \\
B & Yes & No \\
C & Yes & GMP \\
D & Yes & GMP \\
E & No & HACCP \\
F & Yes & GMP \\
G & Yes & GMP \\
H & Yes & HACCP \\
I & Yes & No \\
J & No & HACCP \\
L & Yes & GMP \\
\hline
\end{tabular}

GMP $=$ Good manufacturing practices

The survey outcomes showed that $91 \%$ of the motivations were related to external issues. Companies reported that the main factor for the decision to certify their system in the standard FSSC 220000 was related to increased competitiveness and customer retention. In the current context of the open market, it is vital that companies understand the market requirements and address their strategies to serve them and overcome them. Therefore, competitive advantages should be created based on existing patterns of competition in the market ${ }^{[1]}$

Only one of the participating companies sought the FSSC 22000 certification driven by internal reasons: product quality and safety improvement. It was found that this company is national and operates in the domestic market only, and had already been certified in other ISO management standards.

\subsubsection{Difficulties in the FSSC 22000 implementation process}

Some obstacles to the implementation of systems, programs or quality tools may exist and need special attention of managers ${ }^{[17]}$. The main difficulties in implementing a new management standard, which are identified in the literature, are the lack of knowledge and the resistance of employees, in addition to difficulty in spreading the quality culture and high costs in the implementation of the standard ${ }^{[18]}$. Ribeiro ${ }^{[19]}$, in his research with Portuguese companies, points out that the main reported challenges were the implementation of defined procedures, the resistance of employees and the need for staff training.

Table 3 shows the difficulties reported by the participating companies in relation to the process ranging from the implementation of the standard to its certification. It is noted that the difficulty in developing the HACCP study (Hazard Analysis and Critical Control Points) was stated by almost all companies.

The use of the HACCP study aims to identify and analyze the risks involved, seeking control alternatives in order to ensure the safety of the final product ${ }^{[20]}$. Thus, it is already widespread in the food industry worldwide, since it is widely recognized as the best method to ensure product safety. As it has a very technical approach for its implementation, it becomes especially important to have theoretical and 
Table 3. Difficulties during the FSSC 22000 implementation.

\begin{tabular}{lc}
\hline \multicolumn{1}{c}{ Difficulties } & $\mathbf{N}^{\mathbf{0}}$ of citations \\
\hline Developing the HACCP study & 8 \\
Resistance of employees & 4 \\
Lack of technical knowledge of employees & 4 \\
Short deadline & 4 \\
High cost & 3 \\
Documentation excess & 2 \\
Lack of organizational infrastructure & 1 \\
Lack of top management commitment & 0 \\
\hline
\end{tabular}

practical knowledge. Companies, which had already been certified in any ISO, or had already implemented GMP, stated that HACCP was a difficulty. Companies reported,

[...] due to lack of knowledge on the standard, employees had a lot of difficulty with the HACCP study" and that "the company had no experience in the implementation of a food safety system and had no models or examples of the required documentation. In addition, they did not have any idea about the implementation extension of the reference standard items.

The staff related the greatest difficulties: resistance and lack of technical knowledge of employees.

According to Oliveira and Pinheiro (2010), resistance to change is related to the way of people's thinking and acting as well as organizational culture. It has been seen as one of the main obstacles to the improvement of organizations. Its causes are related to uncertainty, self-interest threat, and different perceptions of the need for change and the lack of tolerance ${ }^{[21]}$. Culture change, followed by resistance of employees, were the greatest difficulties identified in a survey conducted by INMETRO (2005), after interviewing 100 ISO 9001 certified companies ${ }^{[22]}$. Maekawa et al. ${ }^{[17]}$, in his research, highlighted resistance to change by employees and low staff qualification as the major obstacles to system implementation. The resistance of employees to an organizational culture change is naturally expected to be a major challenge for the implementation of a new standard. In fact, it can impede the proper functioning of a management system. In addition to it, the lack of technical knowledge of employees becomes a barrier in the interpretation and implementation of the requirements.

For instance, company A reported that "[...] culture change, linked to low qualification of staff, interfered in the understanding of the importance of necessary requirements and behaviors for food safety assurance."

As suggested by authors ${ }^{[17]}$, there are strategies in order to eliminate or minimize the resistance of employees. They are: raising awareness among staff through lectures and training; clarifying and discuss the implications of the new procedures, benefits and difficulties for both company and employees; simplifying the language of documentation in order to facilitate the comprehension on all levels of operation; working closely with the human resources department during the system implementation and rewarding good performance.

Four companies as one of the difficulties experienced also cited the short deadline, from implementation to certification. The implementation and certification of a standard requires time and dedication of employees. Ribeiro ${ }^{[19]}$ also identified the short term as one of the main difficulties of ISO 9001 certified companies. She highlights the lack of time that most of the employees when devoting to implementation activities and incorporation of a new standard, because sometimes they do more than one function in the organizational structure. She also emphasizes that other authors have also mentioned this difficulty in their papers, such as Bhuiyan and Alam ${ }^{[23]}$ and Gotzamani ${ }^{[24]}$.

Besides, one of the companies that "the short deadline was a difficulty in the certification process, because we had few records for audits, reported it".

More than half of the sample implemented the system between 6 and 12 months (63\%), followed by the range of 12 to 18 months with $30 \%$ of the companies. None of the participating companies exceeded one and a half year to certify the system. It was found that, among the 8 companies, which were certified in less than one year, 6 were motivated by customer demand, which can indicate the short deadline was influenced by market pressure. Market pressure can be considered as constraints placed on trade by the level of demand in the market, for example, "I just buy materials from certified companies").

The implementation of any consequently requires a large financial investment. Although reported only by three companies, the high cost may represent a hindrance for certification of a standard, especially when considering FSSC 22000. Among the major financial investments, informants indicated the adequacy of building infrastructure and facilities (55\%), the laboratory analysis services to meet legal and regulatory requirements $(36 \%)$ and hiring training sessions $(9 \%)$ as the main ones.

For example, company J reported,

\begin{abstract}
[...] the biggest challenge was related to the high cost of implementation, because it involved several expenses, both on the building infrastructure and on necessary analysis. One of them is the analytical process on packaging migration, which is to verify whether any substance in the packaging migrates into the food or beverage. This type of analysis is costly and requires investment by the company.
\end{abstract}

The high cost for implementing FSSC 22000 may be the greatest barrier for small businesses seeking to be certified, since the availability of financial resources was strongly cited by companies as essential for this conquest. Besides, studies on food chain organizations point out small businesses are less likely to have a certificated quality and safety food system due to the financial $\cos \mathrm{t}^{[20]}$.

There was no mention of top management commitment as an experienced difficulty. Thus, one can infer that in every organization there was the support of senior management.

\subsubsection{Certification outcomes}

The key factors, which facilitated the implementation of FSSC 22000 are seen in Table 4. Predominantly considered by eight out of the nine companies that were already certified in (an) other standard(s), having an implemented management system was a major facilitator for the implementation of FSSC 22000. Like other voluntary management standards, which are strongly influenced by ISO 9001, FSSC 22000 was too. In addition, they present very similar management system requirements. 
More than half of the companies reported that senior management commitment was essential for achieving the certification. According to the work developed by ${ }^{[25]}$ and the bibliographic research, among eleven authors, the success of any quality management system primarily depends on a strong commitment of top management. One of the aspects that demonstrates this commitment is the availability of sufficient resources for related activities. The provision of adequate resources for the establishment, implementation, maintenance and updating of the food safety management system is a mandatory requirement of ISO 22000 standard $^{[6]}$. As FSSC22000 requirements implementation is quite expensive, it was expected that the availability of financial resources would be one of the factors often mentioned by respondents.

Regarding consultancy hiring, eight out of the eleven companies reported having received specialized advisory. Among those, only two reported this support as one of the certification success factors. In addition, some companies did not have any activity related to food safety previously implemented. This is an indication that the technical knowledge by those who were responsible for the standard is a key factor, as cited by three companies in the survey. When this knowledge is not at all widespread among those who are responsible for the standard implementation, it is necessary to invest in consultancy. In addition, this service offers guidance, planned intervention in an organization and identifies existing problems, assists in strategic decisions and presents better ways to solve them, with reference to regulatory requirements, promoting impact on results in the short and long term ${ }^{[25]}$.

For organizations, being certified is a very important, voluntary process, considering the fact that the adoption of management practice has an advantage mainly in the international market ${ }^{[26]}$. The certification ensures the organization keeps pursuing improvement in their administrative and production processes $^{[27]}$. The implementation of FSSC 22000 brings many benefits to the organization that aims to develop its concepts and functions. The stated benefits obtained by the eleven respondent companies are presented in Table 5.

About the benefits of certification, it is essential to evaluate the motivations that led the companies to be certified. The motivations can lead to different results depending on the level of commitment of senior management, the awareness of the existing business weaknesses and the availability of financial, physical and human resources ${ }^{[17]}$.

Correlating the main reasons stated by companies seeking the FSSC 22000 certification (access to new markets and customer retention), with benefits accrued after this conquest (improvement of company's image, new customers and access to new markets), it is noted there is relative coherence. These (food and beverages) customers have a global representation and importance in the packaging market, since most of the sales come from the food $(51 \%)$ and beverages (18\%) segments ${ }^{[28]}$. Similarly, in Brazil, the largest packaging consumer market is the food and beverage industry representing $74 \%$ of the domestic packaging purchase ${ }^{[29]}$.
Table 4. Key factors for the successful FSSC 22000 implementation.

\begin{tabular}{lc}
\hline \multicolumn{1}{c}{ Factors } & $\mathbf{N}^{\mathbf{0}}$ of citations \\
\hline Already certified in (an) other standard(s) & 7 \\
Senior management commitment & 7 \\
Availability of financial resources & 6 \\
Technical knowledge of the time & 3 \\
External consulting contract & 2 \\
\hline
\end{tabular}

Table 5. Benefits obtained with the FSSC 22000 certification.

\begin{tabular}{lc}
\hline \multicolumn{1}{c}{ Benefits } & $\mathbf{N}^{\mathbf{0}}$ of citations \\
\hline The awareness of employees & 7 \\
Improvement of company's image & 6 \\
Improvement of quality and safety of this products & 6 \\
New customers and access to new markets & 5 \\
Increased customer satisfaction & 4 \\
Improvement internal organizational & 3 \\
Improvement comunication & 3 \\
Increased productivity & 2 \\
Reduction of non-compliant products & 2 \\
\hline
\end{tabular}

Therefore, it is concluded that being FSSC 22000 certified allows the organization to adapt to market competition standards, a factor that contributes to its competitiveness.

Interestingly, although internal organizational factors were not the certification drivers for some companies, the awareness of employees in relation to product safety and quality improvement was considered among the three major benefits for the organizations, that is, once overcoming the resistance of employees, this aspect becomes a benefit to the organization.

The participating companies were also asked about the level of satisfaction, considering the initial motivations for implementing FSSC 222000 and the results after the certification of this standard. According to their answers ( $55 \%$ satisfied and $45 \%$ very satisfied), it can be concluded that all companies are at least satisfied.

\section{Conclusion}

This paper has enabled progress in mapping and understanding the reality of plastic packaging manufacturers for food and beverages, which are certified according to standard FSSC 220000. It was concluded that, among the reasons that led the companies to seek the certification, the main one was to improve competitiveness and customer retention. The greatest difficulties were related to personnel, which presented technical and behavioral issues. In addition, it was noticed that an overall satisfaction, derived from after-certification benefits, have been arisen in the companies. For instance, an increase in employee awareness, improvement of the company's image and conquest the new customers, significantly contributing to their competitiveness, are some of the benefits found in this process.

The capacity of a product to meet the customer's stated or implied needs through its features ${ }^{[30]}$, i.e., having the assured quality, has long been the key to satisfaction and maintenance of customers in the packaging industry. However, in the current scenario, to be well positioned in the 
market, it is not enough. After FSSC 22000 was published, some of the large food and beverage organizations started demanding the proof of this certification when hiring their suppliers, which became a strong market trend. This fact confirms that FSSC 22000 influences and will influence competitiveness of packaging companies. The presented panorama can support companies that want to develop this type of system and can motivate many organizations to obtain the FSSC 22000 certification, due to the positive data presented here.

\section{References}

1. Carvalho, J. L. M., \& Toledo, J. C. (2002). A Contribuição dos Programas da Qualidade na Competitividade: estudo de caso no mercado brasileiro de polipropileno. Polímeros: Ciência e Tecnologia, 12(4), 240-247. http://dx.doi.org/10.1590/S010414282002000400006.

2. Carvalho, J. L. M., \& Toledo, J. C. (2000). Restruturação Produtiva, Programas da Qualidade e Certificações ISO 9000 e ISO 14000 em Empresas Brasileiras: pesquisa no setor químico/ petroquímico. Polímeros: Ciência e Tecnologia, 10(4), 179192. http://dx.doi.org/10.1590/S0104-14282000000400005.

3. Garcia, R. W. D. (2003). Reflexos da globalização na cultura alimentar: considerações sobre as mudanças na alimentação urbana. Revista de Nutrição, 16(4), 483-492. http://dx.doi. org/10.1590/S1415-52732003000400011.

4. Associação Brasileira das Indústrias de Alimentação - ABIA. (2010). Principais exportadores mundiais de alimentos. São Paulo. Retrieved in 2016, May 26, from http://abia.org.br/vst/ SugestoesINDALparaAlavancagemExportacaoAlimsProcessados. pdf

5. Associação Brasileira das Indústrias de Alimentação ABIA. (2012). A Força do Setor de Alimentos. São Paulo. Retrieved in 2016, May 26, from http://abia.org.br/vst/ AForcadoSetordeAlimentos.pdf

6. Associação Brasileira de Normas Técnicas - ABNT. (2006). Norma Técnica NBR ISO 22000. Sistema de Gestão da Segurança de alimentos: requisitos para qualquer organização na cadeia produtiva de alimentos. São Paulo: ABNT.

7. Vieira, A. C. P. (2009). Instituições e segurança dos alimentos: construindo uma nova institucionalidade (Doctoral thesis). Universidade Estadual de Campinas, Campinas.

8. Wallis, G., Weil, D., \& Madi, L. F. C. (2012). O Mercado de Embalagem no Brasil. Brasil Pack Trends, 2020, 9-39.

9. DATAMARK. (2015). Mercado de embalagem em 2014. Retrieved in 2015, September 20, from http://www.datamark. com.br/dados-gerais

10. Associação Brasileira de Embalagens -ABRE. (2015). Estudo macroeconômico da embalagem. São Paulo. Retrieved in 2016, May 26, from http://www.abre.org.br/setor/dados-de-mercado

11. Foundation for Food Safety Certification - FSSC. (2015). Certificação de Sistemas de Gestão de Segurança dos Alimentos 22000. Retrieved in 2015, November 11, from http://fssc22000. com/downloads/brochurefssc22000_po.pdf

12. Foundation for Food Safety Certification - FSSC. (2015). Certificates Directory. Retrieved in 2015, July 21, from http:// www.fssc22000.com/documents/certified-organizations. $\mathrm{xml}$ ?lang=en

13. Sampieri, R. H., Collado, C. F., \& Lucio, P. B. (2006). Metodologia de pesquisa. São Paulo: McGrawHill.

14. Cooper, D. R., \& Schindler, P. S. (2011). Métodos de Pesquisa em Administração. Porto Alegre: Bookman.

15. Banco Nacional do Desenvolvimento - BNDES (2012). Porte de empresa. Rio de Janeiro. Retrieved in 2015, July 25, from http://www.bndes.gov.br/SiteBNDES/bndes/bndes_pt/ Institucional/Apoio_Financeiro/porte.html

16. Viera, A., Caraschi, J. C., \& Prates, G. A. (2014). Implantação do certificado ISO 9001 em uma empresa no setor de papelão: avaliando seus impactos organizacionais. Brazilian Journal of Biosystems Engineering, 8(3), 263-270. http://dx.doi. org/10.18011/bioeng2014v8n3p263-270.

17. Maekawa, R., Carvalho, M. M., \& Oliveira, O. J. (2013). Um estudo sobre a certificação ISO 9001 no Brasil: mapeamento de motivações, benefícios e dificuldades. Gestão \& Produção, 20(4), 763-779. http://dx.doi.org/10.1590/S0104-530X2013005000003.

18. Silva, M. T. S., Jr. (2013). Beneficios e dificuldades na adoção de um sistema de gestão da qualidade no Rio Grande do Norte (Master's thesis). Universidade Federal do Rio Grande do Norte, Natal.

19. Ribeiro, S. I. (2012). Os beneficios e as dificuldades na certificação da qualidade - Norma NP EN ISO 9001:2008 (Master's thesis). Instituto Politécnico do Porto, São Mamede de Infesta, Porto.

20. Paula, S. L., \& Ravagnani, M. A. S. S. (2009). Lógica Fuzzy como Ferramenta de Decisão na Identificação dos Perigos Significativos e Medidas Preventivas de Controle do Sistema APPCC (Doctoral dissertation). Universidade Estadual de Maringá, Maringá.

21. Oliveira, O. J., \& Pinheiro, C. R. M. S. (2010). Implantação de sistemas de gestão ambiental ISO 14001: uma contribuição da área de gestão de pessoas. Gestão \& Produção, 17(1), 51-61. http://dx.doi.org/10.1590/S0104-530X2010000100005.

22. Instituto Nacional de Metrologia-INMETRO. (2005). Qualidade e Tecnologia. Pesquisa de credibilidade das certificações ISO9001. Retrieved in 2016, June 16, from http://www.inmetro. gov.br/qualidade/pdf/Apresentacao_CB25_Rev0.pdf

23. Bhuiyan, N., \& Alam, N. (2005). An investigation into issues related to the latest version of ISO 9000. Total Quality Management \& Business Excellence, 16(2), 199-213. http:// dx.doi.org/10.1080/14783360500054343.

24. Gotzamani, K. (2010). Results of an empirical investigation on the anticipated improvement areas of the ISO 9001:2000 standard. Total Quality Management \& Business Excellence, 21(6), 687-704. http://dx.doi.org/10.1080/14783363.2010.48 3101 .

25. Soriano, D. R. (2001). Quality in the consulting service - evaluation and impact: a survey in Spanish firms. Managing Service Quality, 11(1), 40-48. http://dx.doi.org/10.1108/09604520110359366.

26. Soares, M. F. (2013). Análise de integração em sistemas de gestão baseados nas Normas ISO 9001, ISO 14001 e OHSAS 18001 em empresas de construção civil (Master's thesis). Universidade Federal do Ceará, Fortaleza.

27. Carvalho, M. M., \& Paladini, E. P. (2012). Gestão da qualidade: teoria e casos. Rio de Janeiro: Elsevier.

28. Wallis, G., Weil, D., \& Madi, L. F. C. (2012). O mercado de embalagem: mundo e Brasil. In C. I. G. L. Sarantópoulos, R. A. Rego (Eds.), Brasil Pack Trends 2020 (pp. 9-39). Campinas: ITAL.

29. DATAMARK. (2015). Mercado de Embalagem 2012. Retrieved in 2015, October 12, from http://www.datamark.com.br/dadosgerais

30. Associação Brasileira de Normas Técnicas - ABNT. (2008). Norma Técnica NBR ISO 9001. Sistema de Gestão da Qualidade - Requisitos. São Paulo: ABNT.

Received: May 23, 2016 Revised: Mar. 15, 2017 Accepted: Apr. 04, 2017 